\title{
CORPORATE SOCIAL RESPONSIBILITY (CSR) PT. GRAB INDONESIA DI ERA NEW NORMAL MASA PANDEMI COVID-19
}

\author{
Novita Damayanti ${ }^{*}$ dan Yuni Ratna Dewi ${ }^{2}$ \\ ${ }^{1,2}$ Universitas Prof. Dr. Moestopo (Beragama), Jakarta, Indonesia. \\ *novita.damayanti@dsn.moestopo.ac.id
}

\begin{abstract}
Today, the social responsibility of a company or better known as CSR has become the subject of discussion among the public and business people. PT. Grab Indonesia, as an Indonesian online transportation application, together with the government, carried out a covid 19 vaccination as an implementation of CSR in the New Normal era of the Covid-19 pandemic in several regions in Indonesia for the elderly and online transportation drivers. This study aims to determine the implementation of Grab Indonesia's "vaccine for the country" Corporate Social Responsibility (CSR) during the new normal period of the covid-19 pandemic. The study uses the CSR concept from John Elkington which reveals the triple bottom line concept, namely profit, people, and planet. This research uses a case study approach. The results showed PT Grab Indonesia in the new normal era carried out CSR by holding a covid-19 vaccination together with the Ministry of Health and the Ministry of Tourism and Creative Economy and several other companies such as Fatigon, Good Doctor, Teh Pucuk as vaccine centers in Bali, Palembang, Banten, West Java and other areas.
\end{abstract}

Keywords: pt grab Indonesia; corporate social responsibility (csr); covid-19; new normal

\begin{abstract}
Abstrak
Dewasa ini, mengenai pertanggungjawaban sosial sebuah perusahaan atau lebih dikenal dengan istilah CSR telah menjadi bahan perbincangan di kalangan publik serta pelaku bisnis. PT. Grab Indonesia sebagai aplikasi transportasi online Indonesia bersama dengan pemerintah melaksanakan vaksinasi Covid-19 sebagai implimentasi CSR pada era New Normal Pandemi Covid-19 di beberapa daerah di Indonesia untuk lansia dan driver transportasi online. Penelitian ini bertujuan untuk mengetahui implementasi Coorporate Social Responsibility (CSR) "Vaksin Untuk Negeri" PT. Grab Indonesia pada masa new normal pandemik Covid-19. Penelitian menggunakan konsep CSR dari John Elkington yang mengungkapkan konsep triple bottom line yaitu profit, people, dan planet. Penelitian ini menggunakan pendekatan kualitatif dengan metode studi kasus. Hasil penelitian menunjukkan PT Grab Indonesia pada era new normal melakukan CSR dengan menyelenggarakan vaksinasi Covid-19 bersama dengan Kementerian Kesehatan dan Kementrian Pariwisata dan Ekonomi Kreatif dan beberapa perusahaan lainnya seperti Fatigon, Good Doctor, Teh Pucuk sebagai sentra vaksin baik di Bali, Palembang, Banten, Jawa Barat dan daerah lainnya untuk mempercepat pembentukan kekebalan kelompok (herd immunity).
\end{abstract}

Kata Kunci: pt grab Indonesia; corporate social responsibility (csr); covid-19; kebiasaan baru

\section{PENDAHULUAN}

Akibat pandemi virus Covid-19 yang melanda Indonesia mengakibatkan terhentinya berbagai aktivitas baik ekonomi, bisnis dan sosial. Setelah hampir 2 tahun pandemi berlangsung maka masyarakat juga harus dihadapakan pada kebiasan-kebiasaan baru atau disebut era new normal. Masa new normal tidak serta merta mebuat perusahaan berhenti dalam beroperasi walaupun pada awalnya Covid-19 membuat semua kegiatan beberapa sempat terhenti. Peralihan kebiasaan dengan metode online dan mengurangi interaksi langsung menjadikan pandemik ini memiliki kebiasaan baru yaitu new normal aktifitas dengan menggunakan masker, jaga jarak, cuci tangan, dan aktifitas beralih ke online. 
Kebiasaan berkumpul dan tatap muka menjadi hal yang harus di hindari pada masa sekarang yaitu masa new normal dimana manusia harus memiliki kebiasaan beradaptasi dengan protokol kesehatan yang ketat dan pola hidup yang berbeda dengan masa sebelumnya. Bahkan pemerintah melakukan berbagai program untuk mendukung era new normal tersebut. Salah satunya yakni melakukan rapid test secara massal.

Pemerintah melakukan upaya dengan memberlakukan pembatasan kegiatan masyarakat berskala besar dan berskala kecil. Sejalan dengan pembatasan ini, pemerintah juga melakukan program vaksinasi untuk memutus penularan virus Covid-19. Pemerintah dengan dukungan berbagai organisasi melaksanakan vaksinasi dengan membentuk sentra-sentra vaksinasi di berbagai daerah di Indonesia.

Kerjasama pemerintah dengan berbagai perusahaan baik badan usaha milik negara (BUMN) dan perusahaan swasta mempercepat melakukan adaptasi dengan menyelenggarakan vaksinasi untuk para lansia (lanjut usia), tenaga kesehatan, pejabat pubik, anggota TNI/Polri, tenaga pendidik serta para pekerja di sektor vital dan krisis. Bahkan kegiatan vaksinasi dilakukan untuk para pekerja yang berhubungan langsung dengan masyarakat yakni para pengemudi ojek online.

Era new normal dimaknai oleh perusahaan sebagai upaya untuk beradaptasi dengan lingkungan tetapi dengan melakukan pencegahan sehingga terjadi yang namanya kekebelan kelompok (Herd Immunity). Salah satu perusahaan yang melakukan adaptasi kebiasan baru yaitu PT. Grab Indonesia, perusahaan transportasi online. Perusahaan PT. Grab Indonesia digandeng oleh Kementerian Kesehatan RI untuk melakukan vaksinasi dengan pendekatan teknologi di berbagai wilayah di Indonesia.

Perusahaan ambil bagian untuk berperan serta memberi kontribusi bagi masyarakat. Dalam konteks ini, PT. Grab Indonesia melakukan program vaksinasi sebagai komitmen untuk mendukung program pemerintah mempercepat memutus penularan Covid-19 di Indonesia. Komitmen ini dimaknai sebagai tanggung jawab sosial perusahaan kepada stakeholders-nya sehingga mampu memperbaiki keadaan yang sebelumnya kurang baik menjadi lebih baik.

Tanggung jawab sosial perusahaan (Corporate Social Responsibility, selanjutnya disebut CSR) kian menjadi perbincangan serius dalam forum-forum korporasi global dalam beberapa tahun terakhir. Di Indonesia, perbincangan mengenai CSR tidak hanya didominasi oleh korporasi global saja, namun sudah masuk pada perbincangan korporasi milik negara dan swasta nasional yang mulai serius dalam menggarap program-program CSR mereka demi mendukung terbentuknya citra perusahaan yang positif (Widhagdha et al., 2019).

PT. Grab Indonesia sebagai perusahaan yang berkaitan dengan bisnis, saat ini merasakan bahwa saat ini perusahaan tidak hanya memperhatikan faktor teknis dan finansial saja dalam menjalankan bisnisnya, tetapi faktor-faktor intagible seperti faktor reputasi juga harus diperhatikan. CSR oleh perusahaan dipandang sebagai sebuah indikator kematangan dan kinerja yang baik dari perusahaan yang menyelenggarakannya.

Perusahaan tidak bisa lepas dari keberadaan masyarakat dalam melaksanakan aktivitas bisnisnya, apalagi perusahaan tersebut berhadapan langsung dengan masyarakat dalam layanan jasa. Maka kondisi ini dimanfaatkan dengan baik oleh PT. Grab Indonesia untuk membangun hubungan yang semakin baik dengan para stakeholdersnya terutama pada masa-masa sulit seperti pandemi Covid-19 saat ini yang masih terjadi.

CSR tidak berdiri sendiri, tetapi sebagai fenomena strategi perusahaan yang mengakomodasi kebutuhan dan kepentingan stakeholdernya. CSR timbul sejak era dimana kesadaran akan sustainability perusahaan jangka panjang adalah lebih penting daripada sekedar profitability. Karena itu, kian banyak pula kalangan dunia usaha dan pihak-pihak terkait mulai merespon wacana tersebut, tidak 
sekedar mengikuti tren tanpa memahami esensi dan manfaatnya.

Sebagaimana pandemi Covid-19 telah memengaruhi kehidupan masyarakat Indonesia selama lebih dari satu tahun terakhir. Meski demikian, pemerintah terus berjibaku untuk bangkit, termasuk dalam memulihkan perekonomian nasional. Salah satu elemen penting dalam mendorong pemulihan ekonomi nasional adalah menjalankan program vaksinasi. Program yang dimulai pada Januari 2021 itu menjadi garis pertahanan terdepan dalam melawan virus corona. Demi menyukseskan dan mempercepat program vaksinasi, pemerintah pun berkolabrasi dengan pihak swasta, seperti Grab Indonesia.

President of Grab Indonesia Ridzki Kramadibrata menilai hal ini merupakan momen yang tepat untuk memperkuat kemitraan antara pemerintah, baik pusat maupun daerah, dengan pihak swasta. "Dengan semangat gotong royong, kita bisa melewati masa sulit ini bersama (R.Kramadibrata, 2021). Sebagai bentuk komitmen tersebut, Grab Indonesia telah memvaksinasi ratusan ribu masyarakat, terutama mitra Grab, di seluruh Indonesia.

Program CSR merupakan investasi bagi perusahaan demi pertumbuhan dan keberlanjutan (Sustainability) perusahaan dan bukan lagi dilihat sebagai sarana biaya (Cost Centre) melainkan sebagai sarana meraih keuntungan (profit centre). Kegiatan CSR penting dalam upaya membangun citra dan reputasi perusahaan yang pada akhirnya meningkatkan kepercayaan baik dari konsumen maupun mitra bisnis perusahaan.

Dari latarbelakang tersebut maka penelitian ini diperkuat dengan konsep CSR disebut dengan Konsep Triple Bottom Line (TBL) merupakan konsep yang dikembangkan oleh John Elkington pada tahun 1997 melalui bukunya yang berjudul "Cannibals with Fork, the Triple Bottom Line of Twentieth Century Business" (Michael et al., 2019). Elkington menyatakan bahwa selain mengejar profit, perusahaan harus memperhatikan dan terlibat pada pemenuhan kesejahteraan masyarakat (people) dan berkontribusi aktif dalam menjaga kelestarian lingkungan (planet). (Ariastini \& Semara, 2019).

TBL merupakan unsur penting yang harus diperhatikan oleh perusahaan. TBL dapat menjadi tolak ukur perusahaan, dengan tidak hanya memperhatikan sisi ekonomi, namun juga dampak yang ditimbulkan baik positif maupun negatif terhadap sosial dan lingkungan. Dalam prakteknya ketiga aspek TBL memiliki hubungan dan keterkaitan yang kuat.

Dalam gagasan tersebut, perusahaan tidak lagi diharapkan pada tanggung jawab yang berpijak pada single bottom line, yaitu aspek ekonomi yang direfleksikan dalam kondisi financial-nya saja, namun juga harus memperhatikan aspek sosial dan lingkungannya. Perusahaan tidak lagi dihadapkan pada tanggung jawab yang berpijak hanya pada single bottle lines yaitu, nilai perusahaan (Corporate Value) yang direfleksikan dalam kondisi keuangannya (financial) saja, tetapi tanggung jawab perusahaan harus berpijak pada triple bottom lines, yaitu berupa: finansial, sosial dan lingkungan (Haerani, 2017).

Dalam konteks ini CSR dimaknai sebagai komitmen bisnis untuk berperilaku etis, beroperasi secara legal dan berkontribusi terhadap pembangunan ekonomi sekaligus meningkatkan kualitas hidup karyawan dan keluarganya, serta masyarakat lokal dan masyarakat pada umumnya. Selain itu, reputasi juga berdasarkan dari kinerja dan bentuk komunikasi yang dilakukan oleh perusahaan. Dengan kinerja yang baik, maka secara tidak langsung reputasi baik akan terbentuk dengan sendirinya. Perusahaan yang baik tidak hanya memburu keuntungan ekonomi belaka (profit) melainkan pula memiliki kepedulian terhadap kelestarian lingkungan (planet) dan kesejahteraan masyarakat (people). (Initiative, 2002 dalam Marnelly, 2012).

Sejalan dengan kondisi ini, Wibisono (2007) dalam (Sofyanty, et al, 2017) juga menjelaskan keterkaitan mengenai ketiga aspek TBL, profit merupakan pendapatan tambahan yang digunakan untuk menjamin kelangsungan 
hidup perusahaan, people merupakan masyarakat yang menjadi salah satu unsur pendukung yang menentukan keberlanjutan perusahaan, dan planet merupakan lingkungan yang memiliki hubungan sebab-akibat dengan perusahaan.

Meningkatnya tingkat kepedulian kualitas kehidupan, harmonisasi sosial dan lingkungan ini juga mempengaruhi aktivitas dunia bisnis, maka, lahirlah gugatan terhadap peran perusahaan agar mempunyai tanggungjawab sosial. Disinilah salah satu manfaat yang dapat dipetik perusahaan dari kegiatan CSR. Dalam konteks inilah aktifitas CSR menjadi menu wajib bagi perusahaan, di luar kewajiban yang digariskan undang-undang (Susanto, 2007) dalam (Marthin et al., 2018)

Secara umum proses pengembangan kegiatan CSR terdapat tiga stakeholders inti, yaitu perusahaan, pemerintah, dan masyarakat diharapkan mendukung penuh. Dalam implemtasi program-program dalam CSR, diharapkan ketiga elemen di atas dapat saling berinteraksi dan mendukung. Oleh karena ini dibutuhkan partisipasi aktif masing-masing stakeholders untuk bergabung di dalam pengambilan keputusan, menjalankan keputusan, dan pertanggung jawaban dari implementasi CSR yang dilakukan bersamasama (Nurjaman, 2012:137). Implementasi Corporate Social Responsibility merupakan tahap aplikasi CSR sebagaimana telah direncanakan sebelumnya. Pelaksanaan CSR membutuhkan iklim organisasi yang saling percaya dan kondusif sehingga menimbulkan motivasi dan komitmen dalam pelaksanaannya.

Banyak organisasi yang telah melibatkan diri dalam aktivitas yang berkaitan dengan pelanggan, karyawan, komunitas dan lingkungan sekitar, yang merupakan titik awal yang sangat baik menuju pendekatan CSR yang lebih luas. Hal ini yang menyebabkan aplikasi dalam pendekatan CSR memiliki cara dan tujuan yang beragam.Aplikasi CSR dilakukan oleh masing-masing organisasi sangat bergantung pada misi, budaya, lingkungan dan profil risiko, serta kondisi operasional masingmasing organisasi. Setiap organisasi memiliki cara masing-masing untuk menentukan program CSR yang akan dilakukan dan bagaimana cara menerapkannya.

Dalam penelitian ini digunakan kajian literatur untuk memperkuat penelitian ini sehingga mampu menunjukkan persamaan dan perbedaan dengan penelitian sebelumnya. Penelitian pertama dilakukan (Rita, 2019), tujuan penelitian ini adalah untuk menganalisis implementasi Corporate Social Responsibility (CSR) di Hotel Grand Clarion Makassar. Penelitian ini menggunakan pendekatan kuantitatif. Obyek penelitian ini adalah Hotel Grand Clarion Makassar. Hasil penelitian menunjukkan bahwa implementasi CSR di Hotel Grand Clarion Makassar sangat tinggi dilihat indikator: (1) Aspek ekonomi berupa dampak ekonomi dari kegiatan operasional yang dilakukan oleh perusahaan, (2) Aspek sosial berupa bentuk perhagaan dari perusahaan yang diberikan kepada stakeholder internal maupun eksternal, dan (3) Aspek lingkungan berupa tindakan perusahaan agar dapat mengurangi dampak negatif terhadap lingkungan.

Persamaan penelitian pertama ini terletak pada tema penelitian yang mengangkat soal CSR, tetapi memiliki perbedaan pada pendekatan penelitian dan metode yang digunakan dalam penelitian ini, sehingga hasil penelitian sangat berbeda juga.

Penelitian kedua dilakukan oleh (Rosilawati \& Mulawarman, 2018), penelitian ini bertujuan untuk mendeskripsikan pelaksanaan CSR yang dipengaruhi oleh kearifan lokal, dengan mengambil studi kasus di Aqua Danone Bali. Penelitian ini menunjukkan proses perencanaan, pelaksanaan dan evaluasi program CSR yang dilaksanakan. Pendekatan yang dilakukan melalui pendekatan kualitatif. Hasil penelitian diperoleh bahwa kearifan lokal Tri Hita Karana (THK) digunakan sebagai dasar program CSR dan muncul dalam setiap tahap CSR mulai dari perencanaan, strategi pelaksanaan hingga evaluasi CSR. Program CSR juga dilaksanakan melalui penggunaan sumber lokal yang tersedia dalam komunitas lokal seperti kearifan lokal 
(Local Wisdom) dan forum-forum lokal untuk melibatkan masyarakat setempat. Masyarakat lokal terlibat dalam proses perencanaan program hingga pada evaluasi program.

Persamaan penelitian kedua terletak pada tema penelitian yang mengangkat soal CSR, pendekatan penelitian dan metode penelitian tetapi memiliki perbedaan pada penggunaan konsep CSR Tri Hita Karana (THK) yang digunakan dalam penelitian ini, sementara penelitian sekarang menggunakan konsep TBL, sehingga hasil penelitian juga berbeda.

Berdasarkan pendahuluan tersebut maka penelitian ini bertujuan untuk menganlisis implementasi kegiatan CSR PT. Grab Indonesia pada era new normal selama masa pandemi Covid-19 melalui "Vaksin Untuk Negeri" di Indonesia sebagai komitmen dan kontribusi bagi masyarakat dan lingkungan.

\section{METODOLOGI PENELITIAN}

Paradigma penelitian yang digunakan dalam penelitian ini adalah paradigma Konstruktivis. Menurut paradigma Konstruktivisme, realitas sosial yang diamati oleh seseorang tidak dapat digeneralisasikan pada semua orang yang biasa dilakukan oleh kaum positivis (Sugiyono, 2016). Paradigma Konstruktivisme menilai perilaku manusia secara fundamental berbeda dengan perilaku alam karena manusia bertindak sebagai agen yang mengkonstruksi dalam realitas sosialnya, baik melalui pemberian makna maupun pemahaman perilaku di kalangan manusia sendiri. Kajian paradigma konstruktivisme ini menempatkan posisi peneliti setara dan sebisa mungkin masuk dengan subjeknya, dan berusaha memahami serta mengkonstruksikan sesuatu yang menjadi pemahaman si subjek yang akan diteliti.

Pendekatan subjektif muncul karena menganggap manusia berbeda dengan suatu benda. Manusia dianggap bebas dan aktif dalam berperilaku dan memaknai realitas sosial. Realitas merupakan hasil interaksi antar individu. (Tamburian, 2018).
Penelitian ini merupakan penelitian kualitatif dengan pendekatan studi kasus. Penelitian kualitatif merupakan proses untuk memahami masalah melalui penggambaran holistik atas masalah tersebut yang dibentuk dengan kata-kata, melaporkan dengan terperinci sesuai sudut pandang informan, dan disusun dalam latar ilmiah (Creswell, 2014). Sedangkan yang dimaksud dengan studi kasus adalah studi tentang kekhususan dan kompleksitas suatu kasus tunggal dan berusaha untuk mengerti kasus tersebut dalam konteks, situasi dan waktu tertentu. Dengan metode ini peneliti diharapkan menangkap kompleksitas kasus teresebut. Kasus itu haruslah tunggal dan khusus. Ditambahkannya juga bahwa studi ini dilakukan karena kasus tersebut begitu unik, penting, bermanfaat bagi pembaca dan masyarakat pada umumnya. Dengan memahami kasus itu secara mendalam maka peneliti akan menagkap arti penting bagi kepentingan masyarakat organisasi atau komunitas tertentu (Patton dalam J.R. Raco, 2010:49)

Yin dalam Creswell, (2014), sediktinya memberikan enam cara pengumpulan data dalam studi kasus yang meliputi; dokumentasi, rekaman, interview, observasi langsung, observasi partisipatoris, dan penggunaan artefak fisik objek penelitian. Penelitian ini merupakan penelitian studi kasus instrumental ( instrumental case study) karena meneliti suatu kasus tertentu agar tersaji sebuah perspektif tentang isu atau perbaikan teori.

Penentuan informan dilakukan secara purposif dengan mempertimbangkan kemampuan informan dalam memberian informasi yang terkait dengan kegiatan CSR Corporate Social Responsibility (CSR) Grab Indonesia pada masa new normal pandemi Covid -19. Penelitian ini tidak bertujuan untuk mengeneralisasi temuan penelitian dan sifatnya kasuistik. Jumlah subjek penelitian akan disesuaikan dengan kepentingan penelitian dan perkembangan dilapangan. 


\section{HASIL DAN PEMBAHASAN}

PT. Grab Indonesia merupakan salah satu perusahaan jasa transportasi online/ daring yang secara konsisten melaksanakan kegiatan CSR. CSR dilaksanakan sebagai bentuk timbal balik positif PT. Grab Indonesia kepada masyarakat Indonesia, dimana perusahaan tersebut menggunakan sumber daya manusia yaitu driver ojek online dan taxi online sebagai mitra usaha Grab.

Reputasi perusahaan merupakan modal paling berharga bagi sebuah perusahaan agar bisa terus berkembang. Hal ini pula yang menjadi awalan perusahaan transportasi online terkemuka PT. Grab Indonesia untuk terus bertumbuh positif. Tak sulit menemukan produk perusahaan yang berbasis aplikasi online dalam bidang transportasi ini. Sebaia perusahaan transportasi online terbesar kedua di Indonesia maka Grab Indonesia memiliki mitra driver yang sangat besar dan tersebar luas di wilayah Indonesia. Dengan berbagai layanan dan feature yang diberikan Grab Indonesia pada masyarakat maka kegiatan tanggung jawab sosial menjadi bagian dari perusahaan yang tidak dapat dihindari. Dengan kondisi Indonesia dan dunia yang sedang dalam pandemik covid 19 maka berbagai kegiatan dilakukan untuk mengurangi dan mengatasi pandemik covid 19 ini.

Salah satu hal yang dilakukan oleh Grab Indonesia dalam kegiatan tanggung jawab sosial adalah kegiatan vaksin covid 19 sebagai bagian dari new normal. Berbagai kegiatan CSR yang dilaksanakan PT. Grab Indonesia bekerjasama dengan berbagai pihak. Pada penelitian ini sebagai studi kasus pada program vaksinasi Covid-19 di Bali, Banten, Bandung dan Solo.

\section{Vaksinasi Covid-19 di Bali}

Kementerian Kesehatan Republik Indonesia menggandeng Grab, super app terkemuka di Asia Tenggara, dan Good Doctor sebagai mitra sektor swasta pertama yang akan melaksanakan program vaksinasi dengan pendekatan yang mengedepankan teknologi. Grab dan Good Doctor akan menjalankan pusat vaksinasi dengan inovasi berupa pilihan jalur Drive-Thru dan Walk-In pertama di Indonesia dan Asia Tenggara.

Pusat vaksinasi pertama akan beroperasi di Bali mulai pada tanggal 27 Februari sampai 5 Maret 2021 untuk gelombang 1 dan pada tanggal 13 sampai 19 Maret 2021 untuk gelombang 2, yang merupakan salah satu daerah yang paling terdampak COVID-19 di bidang industri pariwisata.Pusat vaksin di Bali menargetkan untuk memvaksinasi lebih dari 5.000 pekerja sektor pariwisata, pelaku transportasi umum, mitra pengemudi dan pengantaran layanan transportasi daring (ride-hailing) yang tinggal di Bali. Hal ini bertujuan untuk mencapai kekebalan kelompok (herd immunity) dan mempercepat pemulihan industri wisata di Bali.

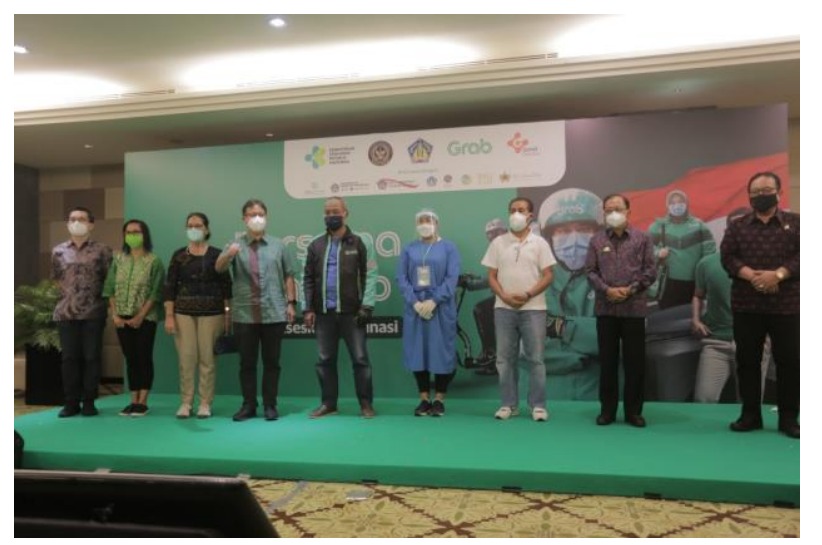

Gambar 1. Program Vaksinasi Di Bali (sumber: Grab Indonesia, 2021)

\section{Vaksinasi Covid-19 di Tangerang}

Menyusul kesuksesan pusat vaksin pertama di Indonesia dan Asia Tenggara yang menghadirkan layanan Drive-Thru dan Walk-In di Bali, Kementerian Kesehatan Republik Indonesia melanjutkan kerja samanya dengan Grab dan Good Doctor untuk meluncurkan pusat vaksin pertama di Indonesia dengan pendekatan 3-in-1 yang mencakup layanan Drive-Thru Mobil dan Motor, serta Walk-In.

Mengacu pada kesuksesan pusat vaksin

Grab di Bali, Kementerian Kesehatan melanjutkan kolaborasi dengan Grab dan Good Doctor untuk menjalankan pusat vaksin di Provinsi Banten dengan pendekatan yang mengedepankan teknologi yang memberikan 
kenyamanan lebih bagi penerima vaksin, terutama para lansia. Proses pra-registrasi, penjadwalan, dan pengelolaan data vaksinasi akan memanfaatkan infrastruktur digital dan teknologi GrabHealth powered by Good Doctor yang bermitra dengan pemerintah untuk memastikan pelaksanaan vaksinasi yang efisien.

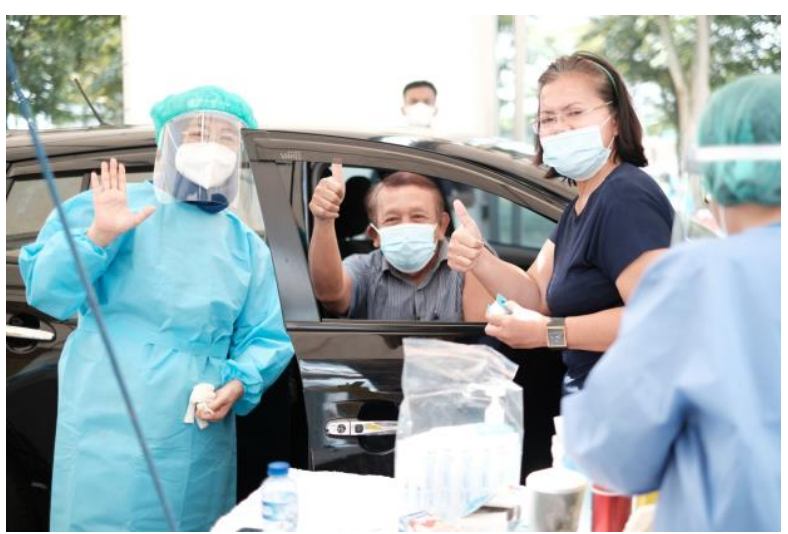

Gambar 2. Vakinasi di Banten

(Sumber: Grab Indonesia, 2021)

\section{Vaksinasi Covid-19 di Bandung}

Setelah sukses menjalankan pusat vaksin dengan pendekatan teknologi di Bali dan pusat vaksin dengan pendekatan 3-in-1 pertama di Indonesia yang mencakup layanan Drive-Thru untuk mobil dan motor serta layanan Walk-In di Provinsi Banten, Kementerian Kesehatan Republik Indonesia kembali berkolaborasi dengan Grab dan Good Doctor untuk menghadirkan pusat vaksin dengan pendekatan 3-in-1 untuk memvaksinasi 5.000 orang lansia dan pekerja sektor publik transportasi, pariwisata, dan media di Kota Bandung, Provinsi Jawa Barat.

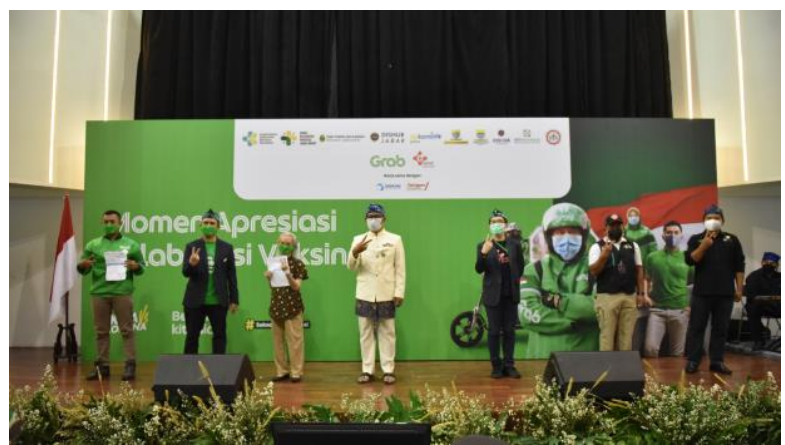

Gambar 3. Vaksinasi Covid-19 di Bandung

(Sumber: Grab Indonesia, 2021)
Grab Vaccine Center di Kota Bandung, Jawa Barat beroperasi pada 16 sampai 18 Maret 2021 di SPORT Jabar Arcamanik untuk gelombang pertama dan pada 20 sampai 22 April 2021 untuk gelombang kedua vaksinasi.

\section{Vaksinasi Covid-19 di Solo}

Surakarta, 22 Maret 2021 - Pemerintah Kota Surakarta melaksanakan vaksinasi tahap 2 yang ditujukan untuk Aparatur Sipil Negara (ASN) dan pekerja publik di sektor transportasi, yang mencakup mitra pengemudi transportasi online dan taksi lokal, termasuk mitra pengemudi dan pengantaran Grab di Balai Kota Surakarta yang dilaksanakan pada 20 sampai 22 Maret 2021. Program vaksinasi ini diresmikan oleh Gibran Rakabuming Raka, Wali Kota Surakarta yang juga hadir untuk meninjau jalannya pemberian vaksin kepada warga Surakarta.

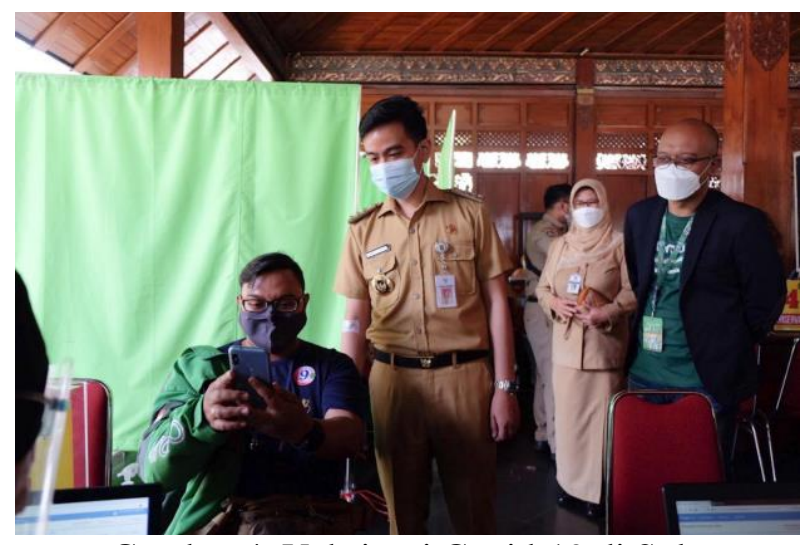

Gambar 4. Vaksinasi Covid-19 di Solo (Sumber: Grab Indonesia, 2021)

\section{Vaksinasi Covid-19 di Palembang}

Setelah sukses menjalankan pusat vaksinasi dengan pendekatan teknologi 3-in-1 di Bali, Banten, Bandung, Solo dan Pekanbaru, Kementerian Kesehatan Republik Indonesia kembali berkolaborasi dengan Grab dan Good Doctor untuk menghadirkan pusat vaksin di Palembang, Sumatera Selatan pada 29-31 Maret 2021 dengan menargetkan vaksinasi kepada 4,600 orang lansia, pekerja publik sektor transportasi dan pariwisata di Palembang selama tiga hari.

Pemilihan tempat pelaksanaan kegiatan CSR PT. Grab Indonesia di beberapa tempat sesuai dengan pendataan dan masukan dari 
berbagai stakeholders khususnya Kementerian Kesehatan dan Pemerintah Daerah. Pelaksanaan difokuskan pada daerah-daerah yang terkait juga dengan keberadaan PT. Grab Indonesia.

Managing Director Grab Indonesia, Neneng Goenadi, mengatakan, kerja sama ataupun kolaborasi antar lembaga ini perlu dilakukan demi mempercepat proses vaksinasi di tanah air. Dengan semangat gotong royong, kami senang dapat berkontribusi dengan memanfaatkan teknologi dan sumber daya yang kami miliki untuk membantu mempercepat proses vaksinasi di seluruh wilayah Indonesia. Membantu Indonesia agar pulih dari pandemi ini, membutuhkan kerja sama dari seluruh sektor dan lapisan masyarakat, dan kami bersyukur diberikan kesempatan untuk ikut berperan serta dalam program vaksinasi.

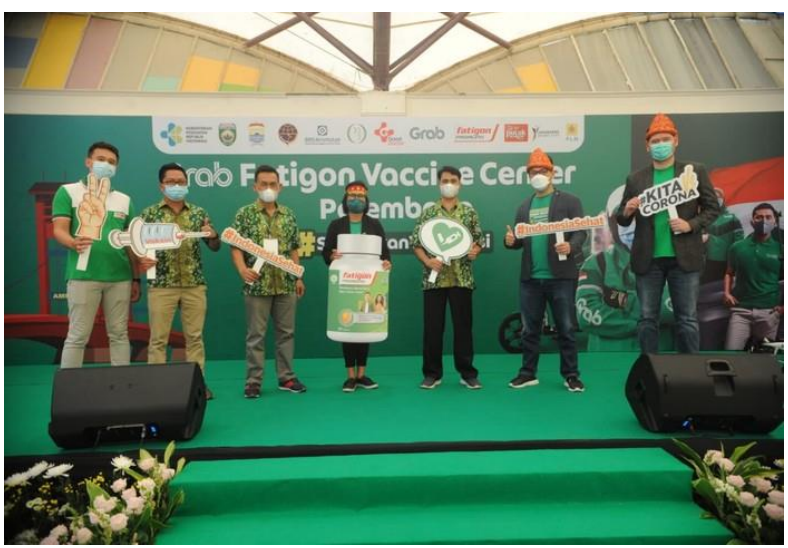

Gambar 5. Vaksinasi di Palembang

Sumber: Grab Indonesia, 2021

\section{Prioritas Vaksinasi Covid-19 Bagi Kelompok Lansia Sebagai Kepedulian}

Sebagai komitmen terhadap masyarakat maka kegiatan CSR difokuskan kepada kelompok Lanjut Usia (Lansia) yang dianggap rentan dengan penyakit sehingga menjadi prioritas perusaaan. Aksesn yang minim juga menjadi alasan perusahaan melakukan vaksinasi bagi kelompok Lansia. Apabila sudah terpapar, mereka susah disembuhkan dan relatif sulit diselamatkan nyawanya. Ini karena dokter juga harus mempertimbangkan penyakit penyerta yang diidap pasien lansia.
PT. Grab Indonesia memprioritaskan Lansian sebab sebagian mereka yang terkena sudah bergejala dan parah sehingga harus dirawat intensif di rumah sakit. Ini tentunya menjadi beban dalam penanganan penyakit di rumah sakit. Dari data yang diperoleh banyak kasus angka kematian akibat Covid-19 tinggi mayoritas mengenai para Lansia yang memiliki penyakit komorbid. Oleh karena itu, vaksinasi pada lansia memang perlu didahulukan. Kegiatan vaksinasi untuk lansia bertujuan untuk mencegah dan menurunkan angka kematian. Kemudahan vaksinasi bagi kelompok Lansia dan para pengemudi online sebagai bentuk kepedulian bagi masyarakat sehingga lingkungan semakin lebih baik melalui program-program yang cepat dan terukur serta dapat dipercaya. Progam vaksinasi bagi Lansia dimaknai perusahaan sebagai upaya menyelematkan masyarakat yang sangat rentan.

\section{Pembahasan}

Sebagai perusahaan yang bergerak dalam sector esensial dalam hal transportasi online, PT. Grab Indonesia memanfaatkan teknologi, jaringan dan jejak operasional yang luas untuk mendukung pemerintah dalam upaya vaksinasi Covid-19 di berbagai aspek dengan memanfaatkan platformnya: a) Grab siap bekerja sama dengan pemerintah untuk menjangkau populasi segmen masyarakat dengan interaksi sosial yang tinggi dan rentan dari aspek geospasial, sosial, dan ekonomi yang perlu segera mendapatkan perlindungan dari virus termasuk para mitra pengemudi, mitra Today, food delivery has become Grab dan agen GrabKios untuk mendapatkan edukasi seputar vaksin; b) Grab menawarkan kerja sama dengan pemerintah dan memanfaatkan platform Grab sebagai saluran komunikasi untuk membagikan konten edukasi kepada jutaan penggunanya dalam rangka memerangi informasi yang salah tentang Covid-19, serta mengedukasi pentingnya vaksinasi dalam mencapai herd immunity untuk memutus rantai penyebaran virus; c) Grab menawarkan layanan konsultasi kesehatan dalam aplikasi (in-app) 
yang ditangani oleh tenaga medis profesional dari Good Doctor untuk menjawab pertanyaan seputar vaksin Covd-19; d) Grab siap berkolaborasi dengan pemerintah dengan berbagai pendekatan untuk mempercepat distribusi vaksin ke seluruh wilayah Indonesia.

PT. Grab Indonesia menganggap bahwa untuk mempercepat pemulihan destinasi wisata di Indonesia khususnya Bali, maka harus segera dilakukan vaksinasi. Maka Kementerian Kesehatan dan Kementerian Pariwisata dan Ekonomi Kreatif menggandeng Grab Indonesia dan Good Doctor Technology Indonesia menggelar vaksinasi massal Covid-19 bagi 5000 pelaku pariwisata, mitra transportasi online maupun angkutan umum.

Kolaborasi ini merupakan bentuk public private partnership yang mana sektor swasta turut membantu pemerintah melaksanakan program vaksinasi nasional Covid-19. Melalui kemitraan ini diharapkan semakin memperluas cakupan vaksinasi, sehingga kekebalan kelompok (herd immunity) bisa segera tercapai.

Bila dikaitkan dengan Konsep CSR John Elkington yaitu konsep triple bottom line (TBL) dalam penerapan CSR di suatu perusahaan, dimana jika perusahaan ingin terus berkelanjutan (sustainable), maka harus memperhatikan 3P, yaitu profit, people, dan planet. Konsep ini menjelaskan hubungan antar menjaga kelestarian sumber daya alam dan lingkungan (planet), keuntungan perusahaan (profit), dan menjaga hubungan dengan masyarakat umum maupun sekitar perushaan (people) atau stakeholdersnya.

Dalam kontes ini, profit merupakan satu bentuk tanggung jawab yang harus dicapai perusahaan dan merupakan orientasi utama dari sebuah perusahaan, seperti keuntungan. Sedangkan people, merupakan masyarakat yang berada di lingkungan sekitar perusahaan atau stakeholders tersebut dan biasanya merupakan penerima langsung dari setiap program yang dijalankan oleh suatu perusahaan. Pada dasarnya masyarakat memiliki hubungan yang kuat dalam rangka menciptakan nilai bagi suatu perusahaan dan ada hubungan timbal balik yang saling menguntungkan.

Sementara itu, Planet adalah lingkungan fisik yang ada di sekitar perusahaan tersebut yang biasanya merasakan dampak langsung dari setiap aktivitas yang dilakukan oleh suatu perusahaan. Setiap aktivitas perusahan yang menyebabkan kerusakan lingkungan tanpa ada penanganan lebih lanjut dari perusahaan terkait dan berlangsung terus menerus cepat atau lambat dapat menghancurkan keseimbangan lingkungan sekitar dan akibatnya akan berdampak buruk bagi perusahaan maupun masyarakat sekitar (Hadi, 2011:56-58).

PT Grab Indonesia menjalankan salah satu P yaitu: People (masyarakat pemangku kepentingan atau stakeholders), menyadari bahwa masyarakat merupakan stakeholder penting bagi perusahaan, karena dukungan mereka, terutama masyarakat pengguna jasa perusahaan sangat diperlukan bagi keberadaan, kelangsungan hidup, dan perkembangan perusahaan, maka sebagai bagian yang tak terpisahkan dengan masyarakat lingkungan, perusahaan perlu berkomitmen untuk berupaya memberikan manfaat sebesar-besarnya kepada mereka.

Pada praktek bisnis, perusahaan perlu menyadari bahwa operasi perusahaan berpotensi memberikan dampak kepada masyarakat (stakeholders), karenanya perusahaan perlu untuk melakukan berbagai kegiatan yang menyentuh kebutuhan masyarakat melalui program vaksinasi karena menyentuh substansi masalah yang dihadapi oleh masyarakat Indonesia bahkan warga dunia.

Dalam masa kini, berbagai aktivitas korporasi membawa dampak yang nyata terhadap kualitas kehidupan manusia baik itu terhadap individu, masyarakat, dan seluruh kehidupan. Terjadinya deforestasi, pemanasan global, pencemaran lingkungan, kemiskinan, kebodohan, penyakit menular, akses hidup dan air bersih, berlangsung terus-menerus hingga akhirnya muncul konsep tanggungjawab sosial perusahaan atau CSR. Gagasan CSR menekankan bahwa tanggungjawab perusahaan 
bukan lagi mencari profit semata, melainkan juga tanggungjawab sosial dan lingkungan. Dasar pemikirannya, ketergantungan pada kesehatan keuangan tidaklah menjamin perusahaan akan tumbuh secara berkelanjutan.

Dalam perkembangan selanjutnya ketiga konsep TBL ini menjadi patokan bagi perusahaan untuk melaksanakan tanggung jawab sosial yang kita kenal dengan konsep CSR. CSR merupakan komitmen usaha untuk bertindak secara etis, beroperasi secara legal dan berkontribusi untuk meningkatkan kualitas hidup dari karyawan dan keluarganya, komunitas lokal, dan komunitas luas. Konsep CSR melibatkan tanggung jawab kemitraan antara pemerintah, perusahaan, dan komunitas masyarakat setempat yang bersifat aktif dan dinamis.

CSR bukan saja upaya menunjukkan kepedulian sebuah organiasasi pada persoalan sosial dan lingkungan, namun juga dapat menjadi pendukung terwujudnya pembangunan yang berkesinambungan dengan menyeimbangan aspek ekonomi dan pembangunan sosial yang didukung dengan perlindungan lingkungan hidup. Dalam rangka merespon perubahan dan menciptakan hubungan kepercayaan, maka upaya yang kini dilaksanakan oleh organisasi (khususnya organisasi bisnis) adalah merancang dan mengembangkan serangkaian program yang mengarah pada bentuk tanggung jawab sosial.

Bentuk-bentuk tanggungjawab sosial yang ideal tentunya bukan hanya muncul semata-mata untuk mencari nama baik sehingga bisa membangun reputasi, namun justru sudah muncul sejak sebuah organisasi berdiri. Sehingga turut pula tertuang dalam visi, misi dan tujuan organisasi. Sehingga pada akhirnya aktivitas tanggung jawab sosial adalah bagian integral dari manajemen stratejik. Dengan turut ambil bagian dalam isu sosial, maka organisasi menunjukkan cerminan dari realitas organisasi yang peduli terhadap fenomena sosial. Sebuah organisasi dalam menjalankan aktivitas tanggungjawab sosial, sudah pasti akan melibatkan publiknya.
Dengan demikian harmonisasi dari sebuah hubungan yang dibina oleh organisasi memperoleh wujud nyata yang akan memberikan manfaat bukan hanya bagi nama baik organiasi namun juga kepada masyarakat secara luas. Keberhasilan organisasi dalam menjalankan tanggung jawab sosial akan memberikan efek "domino" bagi organisasi lain, artinya ada pengaruh yang positif yang akan dipetik oleh organisasi lain untuk melakukan hal yang sama.

Komitmen untuk melakukan tanggung jawab sosial bukan semata-mata untuk investasi sebuah organisasi, namun sudah merasuk pada nafas kehidupan dan keberlanjutan organisasi. Untuk itu setidaknya terwujud setiap keputusan penting dan operasi organisasi, sehingga menjadi bagian dari setiap jenjang dalam organisasi. Pada akhirnya wacana tanggung jawab sosial akan menjadi pemikat bagi semua pihak untuk mewujudkanya secara konkrit dalam tindakan nyata.

\section{SIMPULAN}

PT Grab Indonesia pada era new normal turut serta menjalankan tanggungjawab sosial dengan menyelenggarakan vaksinasi Covid-19 bersama dengan pemerintah. Penyelengaraan vaksinasi covid 19 sebagai komitmen utuk menjaga masyarakat (people) sehingga dapat beraktvitas dari permasalahan yang terjadi saat ini yakni pandemi Covid-19. Komitmen tanggungjawab sosial in untuk menciptkan lingkungan yang lebih baik sehingga segera melewati masa sulit pandemi Covid-19 terjadi pemutusan penularan virus dengan program vaksinasi sehingga terjadi yang kekebalan kelompok (herd immunity) yang semakin cepat dan terwujud. Kegiatan CSR vaksinasi covid 19 dilaksanakan tidak hanya oleh PT Grab melainkan bermitra dengan kementerian kesehatan dan kementria pariwisata dan ekonomi kreatif, Grab sebagai mitra resmi pemerintah dalam penyelenggraan ini. Bersama dengan beberapa perusahaan lainnya menyelengarakan vaksinasi sebagai sentra vaksi baik di Bali, Palembang, Banten, Jawa Barat dan Solo. PT. Grab Indonesia 
berkolaborasu dengan berbagai perusahaan seperti Fatigon, Good Doctor, Teh Pucuk dan lainnya turut serta melancarkan program vaksinasi untuk Indonesia lebih baik dan bebas dari Covid-19.

\section{DAFTAR PUSTAKA}

Ariastini, N. N., \& Semara, I. M. T. (2019). Implementasi Konsep Triple Bottom Line Dalam Program Corporate Social Responsibility Di Hotel Alila Seminyak. Jurnal Ilmiah Hospitality Management, 9(2), $160-168$. https://doi.org/10.22334/jihm.v9i2.155

Hadi, N. (2011). Corporate Social Responsibility. Graha Ilmu.

Haerani, F. (2017). Strategi Corporate Social Responsibility (CSR) dalam Rangka Meningkatkan Reputasi Perusahaan (Dalam Kajian Aspek Hukum Bisnis). Lex Librum: Jurnal Ilmu Hukum, 4(1), 637655.

J.R. Raco. (2010). Metode Penelitian Kualitatif Jenis, Karakteristik, dan Keunggulannya. PT Grasindo.

John W. Creswell. (2014). Research design: qualitative, quantitative, and mixed methods approaches (4th ed). SAGE Publications, Inc.

Marnelly, T. R. (2012). Corporate Social Responsibility: Tinjauan Teori dan Praktek di Indonesia. Jurnal Aplikasi Bisnis, 3(1), 49-59.

Marthin, M., Salinding, M. B., \& Akim, I. (2018). Implementasi Prinsip Corporate Social Responsibility (Csr) Berdasarkan Undang-Undang Nomor 40 Tahun 2007 Tentang Perseroan Terbatas. Journal of Private and Commercial Law, 1(1), 111132.

https://doi.org/10.15294/jpcl.v1i1.12358

Michael, R., Raharjo, S. T., \& Resnawaty, R. (2019). Program CSR Yayasan Unilever Indonesia Berdasarkan Teori Triple Bottom Line. Focus : Jurnal Pekerjaan Sosial, $2(1), \quad 23$. https://doi.org/10.24198/focus.v2i1.23116 Nurjaman, Kadar, K. U. (2012). Komunikasi \&Public Relations. CV Pustaka Setia.

R.Kramadibrata. (2021). Pulihkan Ekonomi Nasional, Grab Dukung Penuh Program Vaksinasi Covid-19. Kompas.Com. Retrieved July 1, 2021, from https://money.kompas.com/read/2021/06/ 28/120808326/pulihkan-ekonominasional-grab-dukung-penuh-programvaksinasi-covid -19 ?page $=$ all .

Rita. (2019). Implementasi Corporate Social Responsibility (Studi Pada Hotel Grand Clarion Makassar). PUSAKA:Journal of Tourism, Hospitality, Travel and Business Event, 1(1), 29-35.

Rosilawati, Y., \& Mulawarman, K. (2018). Corporate Social Responsibility Melalui Kearifan Lokal dalam Program Konservasi Sungai Ayung. Jurnal Ilmu Komunikasi, 16(2), 172. https://doi.org/10.31315/jik.v16i2.2693

Sofyanty, Yossie Ria, et al. (2017). Analisis Penerapan CSR dan Dampaknya Terhadap Kehidupan Sosial Ekonomi Masyarakat (Studi Kasus Pada Hotel Ibis Surabaya City Center). Jurnal Administrasi Bisnis, 42(2), 26-31.

Sugiyono. (2016). Memahami Penelitian Kualitatif. Bandung: Alfabeta. https://doi.org/10.1111/j.1365-

2036.2009.03946.x

Tamburian, H. . D. (2018). Komunikasi Lintas Budaya Masyarakat Dayak Dalam Menjaga Kerukunan Hidup Umat Beragama. Jurnal Komunikasi, 10(1), 77. https://doi.org/10.24912/jk.v10i1.1220

Widhagdha, M. F., Wahyuni, H. I., Sulhan, M., Pembangunan, K., Pascasarjana, S., Mada, U. G., Studi, P., Asia, S., Mada, U. G., Komunikasi, D. I., \& Mada, U. G. (2019). Relasi Bonding Dalam Masyarakat Binaan ( Studi Deskriptif Interpretif Relasi Sosial Masyarakat Binaan CSR PT Pertamina RU II Sungai Pakning di Kabupaten Bengkalis ). 12(1), 108-116. 